\title{
Perbandingan antara Sevofluran dan Enfluran terhadap Kontraksi Uterus, Jumlah Perdarahan, dan Skor APGAR pada Seksio Sesarea Elektif
}

\author{
RR. Pramada Resvita, ${ }^{1}$ Ike Sri Redjeki, ${ }^{2}$ Tatang Bisri ${ }^{2}$ \\ ${ }^{1}$ Bagian Anestesi Rumah Sakit IMC Bintaro, ${ }^{2}$ Departemen Anestesiologi dan Terapi Intensif \\ Fakultas Kedokteran Universitas Padjadjaran /RSUP. Dr. Hasan Sadikin-Bandung
}

\begin{abstract}
Abstrak
Anestetika volatil memiliki sifat fisikokimia yang berbeda-beda yang akan memberikan pengaruh berbeda juga terhadap kontraksi uterus, jumlah perdarahan dan skor APGAR. Tujuan penelitian ini adalah menilai perbedaan pengaruh antara sevofluran dan enfluran terhadap kontraksi uterus, jumlah perdarahan, dan skor APGAR. Penelitian ini adalah randomized controlled trial (RCT) pada 36 pasien seksio sesarea elektif di Rumah Sakit Melinda pada Juni-Agustus 2011. Pasien dibagi dalam dua kelompok: kelompok I (sevofluran) dan kelompok II (enfluran). Analisis data hasil penelitian dilakukan dengan melakukan uji-t, Fisher's Exact Test, dan Uji Mann-Whitney. Hasil penelitian menunjukkan bahwa kontraksi uterus lebih baik pada kelompok sevofluran $(p<0,05)$ dan jumlah perdarahan lebih sedikit pada kelompok sevofluran $(p<0,05)$. Tidak didapatkan perbedaan yang signifikan untuk skor APGAR $(p>0,05)$. Simpulan penelitian ini adalah kontraksi uterus pada seksio sesarea dengan sevofluran lebih baik dibandingkan dengan enfluran dan jumlah perdarahan lebih sedikit pada sevofluran. Skor APGAR pada kedua kelompok tidak menunjukkan perbedaan.
\end{abstract}

Kata kunci: Enfluran, jumlah perdarahan, kontraksi uterus (LAS), seksio sesarea, sevofluran, skor APGAR

\section{Comparison between Sevoflurane and Enflurane Effects on Uterine Contraction, Amount of Bleeding, and APGAR Score in Elective Caesarean Section}

\begin{abstract}
Different volatile agents with different physicochemical properties affect uterine contraction, amount of bleeding, and APGAR score in different ways. The objective of this study was to evaluate the effects of different volatile agents, i.e., sevoflurane and enflurane, on uterine contraction, amount of bleeding, and APGAR score. A randomized controlled trial (RCT) was conducted on 36 patients undergoing elective caesarean section. These patients were randomly divided into two groups, group I (sevoflurane) and group II (enflurane). The data were analyzed using t-test, Mann-Whitney, and fisher exact tests. The result of this study showed that there was a significant difference in the strength of uterine contraction among the sevoflurane group and the enflurane group $(p<0.05)$ and also a significant difference in the amount of bleeding among the two groups $(\mathrm{p}<0.05)$, with better results seen ion the sevoflurane group. However, there was no significant difference found oin the APGAR score among the two groups. It is concluded in this study that sevoflurane gives better results in terms of uterine contraction with less bleeding compared to the enflurane group. No difference is found in the APGAR score in sevoflurane and enflurane groups.
\end{abstract}

Key words: Amount of bleeding, APGAR score, caesarean section, enflurane, sevoflurane, uterine contraction (LAS)

Korespondensi: RR. Pramada Resvita, dr., SpAn, Bagian Anestesi Rumah Sakit IMC Bintaro, Jl. Puter III No. 22 Blok ED 3 Bintaro Java V Tanggerang Selatan, Tlp 021-7456379, Mobile 082115552442, Email vita_hypnose@yahoo.com 


\section{Pendahuluan}

Jumlah seksio sesarea cukup banyak, baik yang bersifat elektif atau emergensi. Seksio sesarea dilakukan dengan memakai anestesia umum, spinal, epidural, atau kombinasi spinal dan epidural. Anestesia umum menjadi jalan keluar bila terdapat kontraindikasi terhadap regional anestesia, penolakan pasien, atau bila waktu tidak memungkinkan untuk dilakukan regional anestesia. Penggunaan anestetika volatil yang poten juga dapat berguna untuk memfasilitasi persalinan sulit yang membutuhkan relaksasi uterus, misalnya pada presentasi bokong, letak lintang, atau pada kehamilan gemeli. ${ }^{1-3}$

Indikasi dilakukan anestesia umum pada seksio sesarea ialah gawat janin, hipovolemia, gangguan fungsi koagulasi, kegagalan anestesia regional, dan juga penolakan terhadap anestesi regional. Teknik induksi pada anestesia umum untuk seksio sesarea dilakukan memakai obatobatan intravena dan rumatan menggunakan anestetika volatil. ${ }^{1}$

Anestetika volatil yang dipergunakan pada seksio sesarea harus memenuhi syarat-syarat seperti mudah mempertahankan kedalaman anestesia sehingga pasien tidak bangun atau tidak terdapat awareness, depresi pada fetus minimal, tidak ada pengaruh yang signifikan terhadap kontraksi uterus serta perdarahan, dan kardiovaskular stabil. ${ }^{4}$

Pengaruh anestetika volatil pada kontraksi uterus dan juga aliran darah akan berbanding lurus dengan dosis yang kita berikan (dose dependent). Anestetika volatil memengaruhi kontraksi uterus melalui gerbang ion $\mathrm{Ca}^{2+}$ serta ion $\mathrm{K}^{+}$, dan menurunkan konsentrasi ion $\mathrm{Ca}^{2+}{ }^{5}$

Anestetika volatil juga dapatmengakibatkan tonus uterus menurun, kondisi ini berpengaruh langsung pada jumlah perdarahan. Penurunan tonus uterus juga berbanding lurus terhadap konsentrasi anestetika volatil yang diberikan., ${ }^{4,5}$

Obat-obat anestesia dapat melewati atau menembus sawar plasenta dan memengaruhi fetus secara langsung, dan dapat menimbulkan depresi pada neonatus. Sebuah penelitian yang terdahulu menarik simpulan bahwa neonatus yang dilahirkan melalui proses seksio sesarea dengan memakai anestesia umum, mempunyai skor APGAR 1 (satu) menit yang lebih rendah bila dibandingkan dengan anestesia regional. ${ }^{1,5}$

Kemampuan anestetika volatil menembus sawar plasenta ditentukan oleh besar molekul, kelarutan dalam lemak, derajat ionisasi, serta struktur kimia obat. Mekanisme transpor zatzat termasuk obat-obatan melalui plasenta adalah dengan mekanisme transpor pasif, aktif, terfasilitasi, dan pinositosis. Faktor-faktor lain yang memengaruhi transpor zat-zat melalui plasenta adalah aliran darah maternal serta fetal, placental binding, metabolisme plasenta, derajat ikatan plasma protein maternal dan fetal, serta usia kehamilan. ${ }^{3,6}$

Paparan anestetika volatil terhadap fetus selain dipengaruhi sifat-sifat farmakokinetik juga oleh permeabilitas plasenta, aliran darah uteroplasenta, dan delivery interval. ${ }^{3}$

Aliran darah uteroplasenta ialah faktor yang sangat berpengaruh terhadap proses transpor oksigen fetus, sehingga ikut menentukan skor APGAR. Anestetika volatil pada 0,5-1,5 MAC tidak akan terlalu banyak memengaruhi aliran darah uteroplasenta, tetapi tingkat kedalaman anestesia memengaruhi tekanan darah, curah jantung, dan aliran darah uterin. ${ }^{3}$

Anestetika volatil yang tersedia pada saat ini adalah halotan, enfluran, isofluran, sevofluran, dan desfluran. Sifat farmakokinetik obat yang berbeda-beda memberikan dampak berbeda terhadap nilai APGAR, kontraksi uterus, serta perdarahan..$^{1-3}$

Tujuan penelitian ini untuk mengetahui perbedaan pengaruh sevofluran dan enfluran terhadap kontraksi uterus, jumlah pendarahan, dan skor APGAR.

\section{Subjek dan Metode}

Penelitian ini bersifat eksperimental dengan cara randomized controlled trial (RCT), double blind. Subjek penelitian terdiri atas 36 wanita hamil aterm yang dilakukan seksio sesarea elektif di Rumah Sakit Melinda dan memenuhi kriteria inklusi yaitu status fisik American's Society of Anesthesiologist (ASA) I-II , usia 1840 tahun, kehamilan pertama hingga ketiga. 
Kriteria eksklusi adalah wanita hamil aterm dengan polihidramnion atau oligohidramnion, kehamilan kembar, hipertensi, disritmia pada elektrokardiografi (EKG), mempunyai riwayat seksio sesarea lebih dari 4 (empat) kali, pasien telah diinduksi dengan drip oksitosin (pitosin infus gagal), preeklamsi, kehamilan disertai mioma uteri. Kriteria pengeluaran adalah bila terjadi hipotensi berat dengan tekanan sistol < $90 \mathrm{mmHg}$ atau tekanan sistol turun lebih dari $30 \%$ dari tekanan darah awal yang menetap, serta terjadi disritmia ventrikel yang menetap.

Setelah peneliti mendapatkan persetujuan dari Komite Etik Penelitian Kesehatan Rumah Sakit Dr. Hasan Sadikin/Fakultas Kedokteran Universitas Padjadjaran, pada pasien yang telah masuk kriteria inklusi dan mengeluarkan yang eksklusi serta menyetujui (informed consent), dilakukan randomisasi mempergunakan tabel bilangan random.

Pasien dibagi ke dalam 2 (dua) kelompok, yaitu kelompok I (sevofluran) dan kelompok II (enfluran). Pemasangan jalur vena dilakukan memakai kanula vena no. 18G ( ${ }^{\circledR}$ Meditop Co), alat pantau EKG, tekanan darah noninvasif, dan juga pulse oksimetri (DINAMAP PRO 1000). Sebagai pengganti cairan puasa, pasien diinfus dengan cairan Ringer laktat $1,5 \mathrm{~mL} / \mathrm{kgBB} / \mathrm{jam}$ dikalikan dengan lama puasa. Infus set yang dipergunakan adalah blood administration set (®Terumo TB*A200L200).

Setelah diukur data dasar tekanan darah, $\mathrm{SpO}_{2}$, pasien diinduksi dengan propofol $2 \mathrm{mg} /$ $\mathrm{kgBB}$, fasilitas intubasi dengan atrakurium 0,5 $\mathrm{mg} / \mathrm{kgBB}$ diventilasi dengan oksigen 100\%, pada kelompok I diberikan volatil sevofluran 2 vol\%, sedangkan pada kelompok II diberikan enfluran 1,7 vol\%. Setelah diintubasi dengan pipa endotrakeal no. 6.5, ventilasi memakai $\mathrm{N}_{2} \mathrm{O} 40 \%, \mathrm{O}_{2} 60 \%$ pada kelompok I diberikan sevofluran 2 vol\%, sedangkan pada kelompok II diberikan enfluran 1,7 vol\%. Setelah bayi lahir tali pusat diklem serta diberikan bolus fentanil 1,5 $\mu \mathrm{g} / \mathrm{kgBB}$ dan diberikan oksitosin $20 \mathrm{U}$ di dalam $500 \mathrm{~mL}$ Ringer laktat dengan kecepatan 40 tetes/menit.

Linear analog scale diukur sesaat setelah tali pusat diklem dan kemudian 3 menit setelah pemberian oksitosin, dan bila LAS kurang dari
6 (enam) maka diberikan metergin $0,2 \mathrm{mg}$ intravena dalam waktu 1 (satu) menit. Jumlah perdarahan diukur dengan menghitung kasa yang digunakan dan menghitung darah dalam botol isap lalu dikurangi dengan cairan untuk membilas. Nilai APGAR dihitung pada menit ke-1, 3, 5, 10 setelah bayi dilahirkan.

Data karakteristik umum penelitian yaitu tekanan darah sistol dan juga diastol, tekanan arteri rata-rata, saturasi oksigen, kontraksi uterus (LAS), interval incision-delivery, serta interval uterine incision-delivery dilakukan analisis menggunakan uji-t, skor APGAR serta penggunaan uterotonika dengan Fisher's Exact Test, jumlah perdarahan dengan uji-t dan Uji Mann-Whitney.

\section{Hasil}

Penelitian dilakukan pada 36 pasien yang menjalani seksio sesarea elektifyang dilakukan dalam anestesia umum. Pasien dibagi menjadi dua kelompok yaitu kelompok sevofluran dan kelompok enfluran. Masing-masing kelompok terdiri atas 18 orang pasien.

Pengujian data umum memakai Uji MannWhitney dan uji-t menunjukkan tidak terdapat perbedaan yang bermakna $(p<0,05)$ pada seluruh parameter yaitu usia, berat badan, tinggi badan, tekanan darah sistol dan diastol, tekanan arteri rata-rata, laju nadi, serta $\mathrm{SpO}_{2}$ antara kedua kelompok perlakuan (Tabel 1).

Kontraksi uterus dinilai dengan melakukan palpasi dengan linear analog scale (LAS). Data hasil pengukuran LAS yang dimulai di titik 0 saat mengklem tali pusat dan kemudian selang 3 menit sampai mulai menutup peritoneum (Tabel 2).

Hasil pengukuran perdarahan didapatkan jumlah pendarahan pada kelompok enfluran lebih banyak dibandingkan dengan kelompok sevofluran dengan perbedaan yang bermakna $(\mathrm{p}<0,05$; Tabel 3$)$.

Skor APGAR pada menit pertama, ketiga, kelima, dan juga kesepuluh tidak didapatkan perbedaan bermakna $(p<0,05)$ antara kedua kelompok. Pada menit kesepuluh nilai skor APGAR tidak dapat dianalisis karena tidak 
Tabel 1 Karakteristik Umum Subjek Penelitian

\begin{tabular}{lccc}
\hline \multirow{2}{*}{ Karakteristik } & \multicolumn{2}{c}{ Kelompok } & \multirow{2}{*}{ Nilai $^{*}$} \\
\cline { 2 - 3 } & Sevofluran (n=18) & Enfluran (n=18) & 0,542 \\
\hline Usia (thn) & & & \\
SD & $29,9(4,0)$ & $30,9(5,0)$ & \\
Rentang & $24-36$ & $23-37$ & 0,366 \\
TB (cm) & & & \\
SD & $159,5(6,9)$ & $161,8(5,9)$ & \\
Rentang & $152-173$ & $153-174$ & 0,288 \\
BB (kg) & & & \\
SD & $69,3(7,3)$ & $71,9(10,0)$ & \\
Rentang & $58-84,5$ & $60-96$ & 0,709 \\
Tekanan darah sistol (mmHg) & 121,5 & 122,7 & 0,156 \\
Tekanan darah diastol (mmHg) & 77,4 & 73,9 & 0,715 \\
Tekanan arteri rata-rata (mmHg) & 91,7 & 92,4 & 0,722 \\
Laju nadi (x/mnt) & 96,7 & 95,17 & 0,367 \\
SpO ${ }_{2}(\%)$ & 99,3 & 99,6 & \\
\hline
\end{tabular}

terdapat perbedaan sama sekali antara kedua kelompokyaitu bayi pada kedua grup mencapai skor APGAR 10 pada menit kesepuluh (Tabel
4). Pengujian menunjukkan bahwa tidak ada perbedaan bermakna antara induction delivery dan uterine incision-delivery kedua kelompok

Tabel 2 Linear Analog Scale (LAS) pada Kelompok Sevofluran dan Enflura berdasarkan waktu

\begin{tabular}{|c|c|c|c|c|c|c|c|c|c|}
\hline \multirow{2}{*}{\multicolumn{2}{|c|}{ Pengamatan }} & \multicolumn{7}{|c|}{ Skor LAS } & \multirow{3}{*}{$\begin{array}{c}\text { Nilai }^{*} \\
0,212\end{array}$} \\
\hline & & \multirow{2}{*}{$\begin{array}{l}4 \\
0\end{array}$} & \multirow{2}{*}{$\begin{array}{l}5 \\
0\end{array}$} & \multirow{2}{*}{$\frac{6}{6}$} & \multirow{2}{*}{$\begin{array}{l}7 \\
9\end{array}$} & \multirow{2}{*}{$\begin{array}{l}8 \\
3\end{array}$} & \multirow{2}{*}{$\begin{array}{l}9 \\
0\end{array}$} & \multirow{2}{*}{$\begin{array}{c}10 \\
0\end{array}$} & \\
\hline 0 & Sevofluran & & & & & & & & \\
\hline & Enfluran & 1 & 0 & 7 & 9 & 1 & 0 & 0 & \\
\hline \multirow[t]{2}{*}{3} & Sevofluran & 0 & 0 & 2 & 7 & 7 & 1 & 1 & 0,003 \\
\hline & Enfluran & 1 & 0 & 6 & 10 & 1 & 0 & 0 & \\
\hline \multirow[t]{2}{*}{6} & Sevofluran & 0 & 0 & 0 & 1 & 7 & 5 & 5 & 0,001 \\
\hline & Enfluran & 0 & 0 & 4 & 11 & 3 & 0 & 0 & \\
\hline \multirow[t]{2}{*}{9} & Sevofluran & 0 & 0 & 0 & 0 & 2 & 4 & 12 & 0,001 \\
\hline & Enfluran & 0 & 0 & 1 & 6 & 10 & 0 & 1 & \\
\hline \multirow[t]{2}{*}{12} & Sevofluran & 0 & 0 & 0 & 0 & 1 & 12 & 5 & 0,001 \\
\hline & Enfluran & 0 & 0 & 0 & 2 & 14 & 0 & 2 & \\
\hline \multirow[t]{2}{*}{15} & Sevofluran & 0 & 0 & 0 & 0 & 0 & 0 & 18 & 0,001 \\
\hline & Enfluran & 0 & 0 & 0 & 0 & 13 & 0 & 5 & \\
\hline \multirow[t]{2}{*}{18} & Sevofluran & 0 & 0 & 0 & 0 & 0 & 0 & 18 & 0,034 \\
\hline & Enfluran & 0 & 0 & 0 & 0 & 4 & 0 & 14 & \\
\hline
\end{tabular}

Keterangan: $0=$ saat diklem tali pusat, $3=3$ menit kemudian, $18=18$ menit kemudian 
Tabel 3 Rata-rata (Std Error) dan Signifikansi Perbedaan LAS untuk Tiap Kelompok (Sevofluran, Enfluran) dalam Tiap Waktu

\begin{tabular}{cccc}
\hline \multirow{2}{*}{ Waktu (mnt) } & \multicolumn{2}{c}{ Kelompok } & \multirow{2}{*}{ Nilai $^{*}{ }^{*}$} \\
\cline { 2 - 3 } & Sevofluran (n=18) & Enfluran (n=18) & 0,212 \\
0 & 6,83 & 6,50 & 0,003 \\
3 & 7,56 & 6,56 & 0,001 \\
6 & 8,78 & 6,94 & 0,001 \\
9 & 9,56 & 7,67 & 0,001 \\
12 & 9,78 & 8,11 & 0,001 \\
15 & 10,0 & 8,56 & 0,340 \\
18 & 10,0 & 9,56 & 0,000 \\
21 & 10,0 & 10,0 & \\
\hline
\end{tabular}

Keterangan: 0=saat diklem tali pusat, 3=3 menit kemudian, 18=18 menit kemudian

$(\mathrm{p}<0,05)$.

Jumlah kebutuhan oksitosin tidak berbeda bermakan antara kedua kelompok, sedangkan jumlah kebutuhan metergin kelompokenfluran lebih banyak dibandingkan dengan kelompok sevofluran, tetapi perbedaan tersebut tidak berbeda bermakna ( $p>0,05$; Tabel 5).

\section{Pembahasan}

Kontraksi uterus diukur dengan menggunakan skala Linear analog scale (LAS). Berdasarkan hasil penelitian ini didapatkan perbedaan signifikan $(p<0,05)$ antarakelompoksevofluran dan enfluran dengan kontraksi uterus yang lebih baik pada kelompok sevofluran (Tabel 2; Tabel 3). Hal ini berkaitan dengan perbedaan sifat karakteristik antara kedua anestetika volatil tersebut. Kontraksi otot berhubungan dengan terbukanya kanal $\mathrm{Ca}+$. Pada penelitian lain didapatkan data bahwa enfluran 0,5-1,5 vol\% akan menyebabkan penurunan kekuatan kontraksi uterus, serta didapatkan juga data bahwa penggunaan enfluran hingga 2 vol\% menyebabkan relaksasi uterus hingga periode pascabedah. ${ }^{4,5,7,8}$

Analisis penelitian ini menunjukkan bahwa kontraksi uterus lebih kuat pada kelompok sevofluran, kondisi ini disebabkan oleh efek enfluran terhadap kanal Ca lebih kuat.

Pada penelitian ini didapatkan perbedaan jumlah perdarahan bermakna antara kedua kelompok perlakuan $(\mathrm{p}=0,001)$, dengan jumlah perdarahan yang lebih sedikit pada kelompok sevofluran. Hal ini berkaitan dengan kontraksi uterus yang lebih baik terdapat pada kelompok sevofluran dibandingkan dengan kelompok enfluran. Kekuatan kontraksi akan berkaitan langsung dengan perdarahan. Pada keadaan atonia uteri dalam waktu 1 jam dapat terjadi perdarahan 2.000-2.500 mL. Keterlambatan mencapai LAS 10 untuk kelompok enfluran menyebabkan perdarahan lebih banyak. ${ }^{9}$

Secara teoritis skor APGAR pada kelompok sevofluran lebih baik bila dibandingkan dengan skor APGAR pada kelompok enfluran, karena enfluran lebih bersifat larut lemak sehingga akan lebih mudah menembus barier plasenta,

Tabel 4 Jumlah Perdarahan

\begin{tabular}{|c|c|c|c|c|c|c|}
\hline \multirow{2}{*}{ Kelompok } & \multicolumn{3}{|c|}{ Jumlah Perdarahan (mL) } & \multirow{2}{*}{ Rata-rata (SD) } & \multirow{2}{*}{ Median } & \multirow{2}{*}{ Nilai $\mathbf{p}^{*}$} \\
\hline & $\pm 500-700$ & $\pm 700-1.000$ & $\geq 1.000$ & & & \\
\hline Sevofluran & 5 & 13 & 0 & $779,21(140,7)$ & 707 & 0,002 \\
\hline Enfluran & 0 & 13 & 0 & $921,72(91,4)$ & 951,5 & \\
\hline
\end{tabular}


Tabel 5 Skor APGAR pada Kelompok Sevofluran dan Enfluran

\begin{tabular}{cllccc}
\hline \multirow{2}{*}{ Menit } & Kelompok & \multicolumn{3}{c}{ Skor APGAR } & \multirow{2}{*}{ Nilai $\mathbf{p}^{*}$} \\
\cline { 3 - 5 } & & $\mathbf{6}$ & $\mathbf{8}$ & $\mathbf{1 0}$ & \\
\hline \multirow{2}{*}{1} & Sevofluran & 7 & 11 & 0 & 0,735 \\
& Enfluran & 8 & 10 & 0 & \\
3 & Sevofluran & 1 & 13 & 4 & 0,595 \\
& Enfluran & 2 & 14 & 2 & \\
5 & Sevofluran & 0 & 3 & 15 & 0,070 \\
& Enfluran & 0 & 6 & 12 & \\
\multirow{2}{*}{10} & Sevofluran & 0 & 0 & 18 & 0,000 \\
& Enfluran & 0 & 0 & 18 & \\
\hline
\end{tabular}

tetapi pada penelitian ini tidak didapatkan hasil yang bermakna antara kedua kelompok. Skor APGAR dipengaruhi oleh aliran darah uteroplasenta yang adekuat. Berbagai faktor dapat memengaruhialiran darah uteroplasenta yaitu kontraksi uterus, penurunan aliran darah uterus, kondisi patologik, serta obat-obatan. Aliran darah uteroplasental dipengaruhi oleh tekanan darah uterina, tekanan vena uterina, dan resistensi vaskular uterus. ${ }^{1,10,11}$

Tidak terdapat perbedaan tekanan darah yang bermakna antara kedua kelompok. Hal ini berarti tidak ada perbedaan tekanan arteri uterina yang akan memengaruhi skor APGAR. Tekanan vena uterina dipengaruhi oleh waktu uterine incision-delivery, pada penelitian ini tidak ada perbedaan bermakna tekanan vena uterina karena tidak ada perbedaan inductiondelivery serta uterine incision-delivery antara kedua kelompok perlakuan. Induksi-delivery harus kurang dari 10 menit dan insisi-delivery harus kurang dari 180 detik. ${ }^{1,12}$

Pengaruh kontraksi uterus terhadap skor APGAR tidak terlihat, hal ini disebabkan semua pasien yang diambil untuk sampel penelitian merupakan kasus seksio sesarea elektif yang dilakukan seksio sesarea sebelum terjadi his/ kontraksi uterus.

Faktor lain yang berpengaruh adalah obat anestesia. Obat induksi intravena (propofol) danpelumpuhototdisamakan antarakelompok sevofluran dan enfluran, sehingga pengaruh terhadap skor APGAR ditentukan berdasarkan perbedaan profil antara anestetika sevofluran dan enfluran. Penelitian menunjukkan bahwa pemberian enfluran lebih dari 1 vol\% akan menurunkan aliran darah uteroplasenta dan juga menimbulkan fetal asidosis. Penelitian ini memakai enfluran 1,7 vol\% serta sevofluran 2 vol\%, tetapi tekanan darah arteri tetap disamakan dan dipertahankan sistol di atas 90 mmHg dengan tujuan mempertahankan aliran darah uteroplasental tetap adekuat.

Induction-delivery dan juga uterine incisiondelivery memegang peranan penting untukskor APGAR. Induction-delivery lebih lama dari 10 menit berakibat buruk pada neonatus dengan bukti penurunan skor APGAR, demikian juga bila uterine incision-delivery lebih dari 180 detik. Pada penelitian ini tidak ada perbedaan antara induction-delivery dan uterine incisiondelivery antara kedua kelompok, sehingga efek

Tabel 6 Waktu Induction Delivery dan Uterine Incision-delivery pada Kelompok Sevofluran dan Enfluran (Detik)

\begin{tabular}{lccc}
\hline \multirow{2}{*}{ Parameter } & \multicolumn{2}{c}{ Kelompok } & \multirow{2}{*}{ Nilai $\mathbf{p}^{*}$} \\
\cline { 2 - 3 } & Sevofluran $(\mathbf{n = 1 8})$ & Enfluran $(\mathbf{n = 1 8})$ & \\
\hline Induction delivery & 243,06 & 241,22 & 0,507 \\
Uterine incision-delivery & 24,06 & 24,22 & 0,894 \\
\hline
\end{tabular}


induction-delivery dan uterine incision-delivery sebagai faktor yang memengaruhi skor APGAR dari dapat dikesampingkan. ${ }^{12}$

Anestetika volatil memengaruhi tekanan darah dengan mekanisme memengaruhi kerja jantung karena bersifat inotropik negatif serta vasodilator. Perbedaan karakteristik antara sevofluran dan enfluran memberikan dampak klinisyangberbeda.Padasistemkardiovaskular sevofluran memberikan hemodinamik lebih stabil karena sifat inotropik negatif sevofluran kurang bila dibandingkan dengan enfluran dan sifat vasodilator sevofluran yang tidak sehebat enfluran. ${ }^{1,2}$

Pada hasil penelitian ini tidak didapatkan perbedaan yang signifikan $(\mathrm{p}<0,05)$ kondisi hemodinamik antara kelompok sevofluran dan enfluran. Hal ini terjadi karena dosis yang digunakan dalam rentang 1-1,5 MAC, sehingga dosis anestetika volatil yang digunakan dapat disesuaikan dengan hemodinamik pasien. ${ }^{3}$

Kondisi hemodinamik maternal terutama tekanan darah memengaruhi kontraksi uterus serta aliran darah uteroplasenta. Penurunan tekanan darah lebih dari $20 \%$ dari tekanan darah awal akan menurunkan kontraksi uterus dan menurunkan aliran darah uteroplasenta yang akan memengaruhi kondisi fetus.

Pada hasil penelitian ini didapatkan kondisi hemodinamik yang stabil dengan sistol yang tidak lebih rendah dari $90 \mathrm{mmHg}$ pada kedua kelompok, sehingga penurunan tekanan darah dapat disingkirkan sebagai faktor penyebab memburuknya kontraksi uterus atau kondisi fetus.

Desaturasi pada pasien akan menurunkan oksigenasi bagi otot-otot uterus dan oksigenasi bagi fetus. Hal ini akan menurunkan kontraksi uterus dan menyebabkan penurunan kondisi fetus. Selama penelitian ini berlangsung tidak terjadi desaturasi pada kedua kelompok.

Oksitosin drip (first-line drug uterotonika) diberikan rutin pada pasien seksio sesarea, sedangkan metergin bolus (second-line drugs uterotonika) dan prostaglandin F-2 (third-line drug uterotonika) diberikan bila ada indikasi bila LAS $<6$ setelah pemberian oksitosin. Pada penelitian ini jumlah metergin dan juga jumlah prostaglandin (sitotex) yang diberikan lebih banyak pada pasien yang dianestesia dengan enfluran. Hal ini sesuai dengan hasil penelitian ini, LAS 10 dicapai lebih lama pada kelompok enfluran, serta pasien yang nilai LAS $<6$ lebih banyak pada kelompok enfluran., ${ }^{3,12}$

Data penelitian secara in vitro menunjukkan bahwa pemakaian konsentrasi enfluran 1-1,5 vol\% dapat menurunkan kontraksi uterus, sedangkan pengaruh sevofluran terjadi pada konsentrasi 3 vol\%. ${ }^{8}$ Pada prosedur penelitian ini rumatan anestesia yang digunakan adalah 1 MAC enfluran (1,5 vol\%) atau 1 MAC sevofluran (2,0 vol\%). Uterotonika diberikan untuk menghindari perdarahan sebagai akibat kontraksi uterus yang tidak baik, oleh karena perbedaan efek enfluran dengan sevofluran terhadap kontraksi uterus, maka logis apabila pemakaian uterotonika lebih banyak terdapat pada kelompok enfluran. ${ }^{5}$

\section{Simpulan}

Simpulan pada penelitian ini adalah pengaruh sevofluran bila dibandingkan dengan enfluran pada seksio sesarea adalah kontraksi uterus yang lebih baik dan perdarahan lebih sedikit, namun tidak terdapat perbedaan skor APGAR antara kedua kelompok.

\section{Daftar Pustaka}

1. Chestnut DH. Obstetric anesthesia principles and practice. Edisi ke-3. Philadelphia: Elsevier Mosby; 2004.

2. Morgan GE, Mikhail MS. Clinical anesthesiology. Edisi ke-4. New York: McGrawHill; 2006.

3. Barash PG, Cullen BF. Clinical anesthesia. edisi ke-5. Philadelphia: Lippincot Williams \& Wilkins; 2006.

4. Munson ES, William JE. Enflurane, isoflurane, halothane and isolated human uterine muscle. J Anesthesia. 1977;46:114.

5. Yoo KY, Lee JC, Yoon MH. The effect of volatile anesthetics on spontaneous contractility of isolated human pregnant uterine muscle: a comparison among, 
sevoflurane, desflurane, isoflurane and halothane. Anesth Analg. 2006;103:443-7.

6. Wray S. Insights into the uterus. Exp Physiol. 2007;621-31.

7. Yamakage $M$, Tsujiguci $N$, Chen $X$. Sevoflurane inhibits contraction of uterine smooth muscle from pregnant rats similarly to halothane and isoflurane. C J Anesth. 2002;49(1):62-6.

8. Kafali H, Kaya T, Gursoy S. The role of $\mathrm{K}^{+}$channels on the inhibitor effect of sevoflurane in pregnant rat myometrium. Anesthesia Analgesia. 2002;94:174-8.

9. Khan FA, Khan M, Ali A, Chohan U. Estimation of blood loss during caesarean section: an audit. J Pak Med Assoc. 2006;56(12):572-5.

10. Abboud TK, Schnider M, Wright RG. Enflurane analgesia in obstetrics. Anesthesia Analgesia. 1981;60:133-7.

11. Sprung J, Flick RP, Wilder RT, Katusio SK. Anesthesia for cesarean delivery and learning dissabilities in a populationbased birth cohort. American Society of Anesthesiologist. 2009;111:302-10.

12. Sanjay D, Harris AP, Witter FR. Anesthetic and obstetric management of high risk pregnancy. Edisi ke-3. New York: Spinger; 2004. 